\title{
Transformational Leadership and R\&D Innovation: Taking a Curvilinear Approach
}

\author{
Silke A. Eisenbeiß and Sabine Boerner
}

Only few studies have examined innovation at the team level so far. Moreover, there are different positions when it comes to the role of leadership in engendering $R \& D$ team innovation. Innovation research outlines that high levels of team autonomy are beneficial to innovation in R\&D teams and thus suggests that leaders should give as little intellectual guidance as possible. Leadership research proposes transformational leadership as a lever for facilitating team innovation. We integrate these two perspectives by arguing for a U-shaped relationship between transformational leadership and $\mathrm{R} \& \mathrm{D}$ team innovation. This hypothesis was supported by data from 52 R\&D teams of international companies.

\section{Introduction}

C reativity and innovation are crucial for organizations to succeed (Arthur D. Little, 2004; Cho \& Pucik, 2005; Dougherty, 2006), in particular for those operating in the research and development sector (Elkins \& Keller, 2003). Most organizational research and development activities are organized as team work because 'teams can be hotbeds of creativity and innovation' (Pirola-Merlo \& Mann, 2004: 255). Unfortunately, however, the amount of research dealing with $R \& D$ team innovation is rather small (Kurtzberg \& Amabile, 2001; West, 2002b; Anderson, de Dreu \& Nijstad, 2004).

We address this lack of research by analysing and empirically examining the role that leadership may play for team innovation in the R\&D sector. Looking at the existing literature on team innovation, there are two research traditions that have tackled this issue but which have come up with different suggestions. Innovation research primarily outlines that R\&D team members inherently have high intrinsic motivation (Deci, Connell \& Ryan, 1989), expert knowledge (Janz, Colquitt \& Noe, 1997), and a high need for autonomy (Realin, 1985). They thus are expected to have a low need for leadership (de Vries, Roe \& Taillieu, 1999). Hence, this stream of research suggests giving R\&D teams as much intellectual autonomy and as little guidance as possible in order to enhance their creativity and innovativeness (Amabile \& Gryskiewicz, 1989; Anderson \& King, 1993).

In contrast, leadership research proposes transformational leadership as a lever for engendering team innovation (Waldman \& Bass, 1991). Transformational leaders display creative behaviour themselves, develop attractive visions of future states, emphasize change, empower team members, encourage their 'out-of the-box' thinking (Bass, 1985, 1998; Bass \& Riggio, 2006), promote co-operation among team members, and strengthen team potency (Schaubroeck, Cha \& Lam, 2007). Unfortunately, empirical studies on the relationship between transformational leadership and team innovation in the R\&D sector are rare and show mixed results (Waldman \& Atwater 1994; Keller 2006; Eisenbeiß, van Knippenberg \& Boerner, 2008).

This paper aims at integrating these streams of research by arguing for a U-shaped relationship between transformational leadership and R\&D team innovation. More precisely, we expect R\&D teams to be highly innovative under low levels of transformational leadership because of R\&D team members' intrinsic motivation to innovate, their technical skills and expert knowledge. Accordingly, low levels of transformational leadership seem to protect R\&D team members' autonomy and correspond to their low need for leadership. 
Due to the expected innovation-enhancing potential of transformational leadership described above, we also argue for high R\&D team innovation to appear under high levels of transformational leadership. However, transformational leadership is likely to have a negative side effect as charismatic and visionary leadership behaviours may be interpreted as strong intellectual guidance and thereby threat team members' autonomy. Under moderate levels of transformational leadership this negative effect and the innovation-beneficial effect of transformational leadership may cancel each other out and thus result in low levels of R\&D team innovation.

\section{Theoretical Background}

\section{Innovation in RED Teams}

Innovation is defined as 'the intentional introduction and application within a role, group or organization of ideas, processes, products or procedures, new to the relevant unit of adoption, designed to significantly benefit the individual, the group, organization or wider society' (West \& Farr, 1990: 9). Creativity refers to 'the production of novel and useful ideas' (Amabile, 1988: 126). As R\&D team innovation encompasses both idea generation and idea implementation (West, 2002a), team creativity can be regarded as the ideation component of team innovation (Rank, Pace \& Frese, 2004). R\&D team innovation can be assessed as a combination of quantity of developed and implemented ideas and their quality in terms of novelty, magnitude, radicalness and effectiveness (West, 2002b; Pirola-Merlo \& Mann, 2004).

Research on creativity and innovation suggests that team members' creativity can be best stimulated by providing employees with high levels of autonomy and high degrees of intellectual freedom (Amabile \& Gryskiewicz, 1989; Anderson \& King, 1993). First, R\&D team members are highly qualified 'knowledge workers' (Friedman, Fleishman \& Mikula Fletcher, 1992; Janz, Colquitt \& Noe, 1997; Kim, Min \& Cha, 1999). Most researchers in $R \& D$ teams hold a PhD degree and thus can be regarded as highly educated professionals in their field. Second, R\&D team members are characterized by high degrees of intrinsic motivation (Deci, Connell \& Ryan, 1989). As researchers and experts, members of $R \& D$ teams are primarily motivated by their research tasks, as opposed to extrinsic rewards, such as financial or similar compensation. Third, research and development tasks do not inherently involve given solution patterns and definitive outcome expectancies (Kanter, 1988; Mumford et al., 2002) and thus imply high levels of complexity. R\&D team members may need a high degree of decision autonomy on procedures, resources and time schedules in order to develop and test creative ideas (Oldham \& Cummings, 1996; Kim, Min \& Cha, 1999). In addition, having high degrees of autonomy is part of researchers' professional identity (Realin, 1985). Mainly driven by intellectual curiosity, R\&D team members are supposed to have strong motivation regulation processes, enjoy developing their own vision for the future, set themselves long-term objectives and milestones. Therefore, they are likely to have a high need for autonomy and thus a low need for leadership (de Vries, Roe \& Taillieu, 1999).

\section{Transformational Leadership and RED Team Innovation}

Based on Burns' (1978) seminal work, Bass (1985) translated the distinction between transactional and transforming political leadership into the organizational context and developed a theory of transformational leadership. In his Full Range of Leadership Theory, Bass (1985) claimed to cover the whole spectrum of leadership styles, distinguishing between laissez-faire, transactional leadership and transformational leadership. Laissez-faire, the so-called 'nonleadership factor' (Northouse, 2007: 186), is characterized by the absence of leadership. For example, the laissez-faire leader does not set goals, gives no feedback and does not support followers in their efforts. Transactional leadership comprises continuous reward with managementby-exception (active and passive). Active management by exception includes the leader's corrective actions in case rule violations or mistakes are to be expected. In contrast, a leader using the passive form of management by exception will interfere only when problems have arisen. Transactional leadership thus emphasizes the exchange relationship between a leader and his or her followers. In the Full Range of Leadership Theory, transactional leadership is regarded as a prerequisite of transformational leadership.

Transformational leaders are assumed to 'motivate people to do their best' (Avolio \& Bass, 1988: 33) and make their followers perform beyond expectations by moving them to transcend their own self-interest for a higher purpose or vision (Bass, 1985, 1998; Bass \& Riggio, 2006). Bass and Avolio (1994) characterized transformational leadership as comprising four components. Idealized 
influence refers to charismatic role modelling behaviour of transformational leaders. As a result, leaders are trusted and respected, and followers want to emulate them. Inspirational motivation means that transformational leaders provide meaning to followers' work by articulating an appealing or evocative vision for the team or the organization. Intellectual stimulation means that these leaders encourage followers to challenge existing assumptions, reframe problems and approach old situations in new ways. Individualized consideration relates to coaching and mentoring behaviour of transformational leaders that take individual differences between followers into account.

Transformational leadership seems to be different from traditional leadership styles as it is more about emphasizing change and envisioning (Conger \& Kanungo, 1992; Avolio, 1994). Hence, transformational leadership theory is regarded as a promising approach to foster team creativity and innovation (Waldman \& Bass, 1991). First, transformational leaders display unconventional and creative behaviour themselves and serve as a role model (Bandura, 1998) for being innovative. Given that transformational leadership enhances followers' personal identification and produces strong emotive attachment (Kark, Shamir \& Chen, 2003), followers may strive for emulation and, therefore, innovative behaviour. Second, by providing intellectual stimulation, transformational leaders encourage team members to think 'out of the box' (Jung, Chow \& Wu, 2003) and adopt an explorative thinking style. Additionally, they point out different and unusual perspectives to look at old problems and thereby stimulate team members to critically appraise existing assumptions and working methods (Bass, 1985) which in turn should enhance innovation in R\&D teams. Third, transformational leadership emphasizes collective interests and induces team members to transcend their own self-interest for the betterment of the team (Bass et al., 2003). As a result, team members attach high importance to team membership and are more willing to engage in efforts for the sake of the team (Shamir, House \& Arthur, 1993; Bass \& Riggio, 2006). Therefore, transformational leadership is expected to encourage team members to collaborate and to assist each other with idea development and implementation and thus promote support for innovation (West, 1990). Fourth, by communicating a high level of confidence in the team's ability to achieve ambitious collective goals (Podsakoff et al., 1990) transformational leaders are likely to strengthen team potency (Schaubroeck, Cha \& Lam, 2007). Team potency is defined as team members' 'generalized beliefs about the capabilities of the team across tasks and contexts' (Gully et al., 2002). Thus, transformational leaders also help team members to reach the future states articulated in the vision.

However, although theoretical analysis suggests a positive relationship between transformational leadership and R\&D team innovation, the empirical evidence is scarce and mixed. Whereas Keller $(1992,2006)$ showed in a crosssectional as well as in a longitudinal design that transformational leadership is positively related to R\&D team performance, Waldman and Atwater (1994) did not find a relationship between transformational leadership displayed by direct project leaders and R\&D team project performance.

\section{Integrating the Two Perspectives}

In sum, the existing body of research proposes two ways for facilitating R\&D team innovation. In order to integrate these positions and to give an explanation for the inconsistent empirical evidence regarding the relationship between transformational leadership and team innovation, we predict a U-shaped relationship between transformational leadership and R\&D team innovation. More precisely, we argue that transformational leadership needs certain levels of intensity to result in engendering R\&D team innovation. Given the high need for autonomy of R\&D team members (Realin, 1985), leaders' attempts at intellectual guidance, involving charismatic and visionary leadership behaviours, may interfere with team members striving for intellectual freedom and for latitude in fulfilling their work assignments. Hence, transformational leadership may be interpreted as a potential threat to team members' intellectual autonomy and result in endangering team innovation. Renouncing or substantially reducing the levels of transformational leadership preserves team members' intellectual autonomy and thus ensures one of the most important preconditions for innovation in $R \& D$ teams. Therefore, we expect high levels of $R \& D$ team innovation under low levels of transformational leadership.

However, by acting as a role model for creative behaviour, by encouraging alternative thinking approaches and by boosting team potency, transformational leaders may be able to increase team members' already high levels of work motivation and creativity and produce high levels of R\&D team innovation (Bass \& Avolio, 1994). Still, the positive influence of transformational leadership on team innovation may hold only for high levels of transfor- 
mational leadership when leaders are highly respected and admired by the team members and their vision for the future creates strong team identification and commitment. Below certain levels of intensity, the negative side effect of transformational leadership - that is, endangering the team's intellectual autonomy - might be equal to its beneficial effect on R\&D team innovation. A moderate level of transformational leadership will thus not facilitate $R \& D$ team innovation, but produce low levels of $R \& D$ team innovation. In order to exceed this negative side effect and thus foster team innovation, a high level of transformational leadership may be needed.

Hypothesis: There is a $U$-shaped relationship between transformational leadership and innovation of RED teams.

\section{Method}

\section{Sample}

The sample comprised 52 research and development teams from one research institute and seven international R\&D companies engaged in different industries (i.e., automotive, semiconductor, packaging, machinery, consumer goods, and scientific instruments). A total of 52 team leaders and 256 employees participated in the study. Team leaders were primarily men (78.8 per cent) and were between 32 and 57 years of age, with the average age being 43 . They had worked on average 22 years with the company and had a range of tenure from 2 to 34 years. Team members had worked an average of 9 years with the company ranging from 1 year to 33 years and were between 25 and 58 years of age, with the average age being 37 years. The majority of team members (78.2 per cent) were men. Average team size was 9.1 team members and average team tenure was 39.2 months. The minimum number of responding team members necessary for inclusion was two members per team, with the average response rate within the teams being 57.0 per cent.

\section{Procedure}

After agreeing to participate, each team leader was instructed about objectives and procedure of the internet-based study via e-mail or telephone. Anonymous and strictly confidential data treatment was assured. When we launched the survey, team leaders were given the link to get on the website and a randomly generated team code. This code had to be entered on the first page of the survey to ensure that responses of leader and members belonging to the same team could be matched afterwards. Team leaders were asked to pass the provided information to their team members and encourage them to participate. Team members were surveyed about perceptions of their team leader's transformational leadership, while information on team innovation was obtained from the team leaders.

\section{Measures}

\section{Transformational Leadership}

We measured transformational leadership using a 20-item scale from the Multifactor Leadership Questionnaire (MLQ) developed by Bass and Avolio (1995). The MLQ is the most common measure of transformational leadership (Yukl, 1998; Judge et al., 2006). All four theoretically identified components of transformational leadership are operationalized in the MLQ. Items were rated on a 7-point scale ranging from 1 (never) to 7 (almost always). Sample items are "The leader talks about his/her most important values and beliefs' (idealized influence), 'The leader talks enthusiastically about what needs to be accomplished' (inspirational motivation), 'The leader seeks differing perspectives when solving problems' (intellectual stimulation) and 'The leader spends time teaching and coaching' (individual consideration).

\section{Team Innovation}

To measure team innovation it is necessary to cover both stages of idea development and idea implementation and to take into account quantity as well as quality of innovation (West, 1990, 2002a). Accordingly, team innovation was measured using a 22-item scale based on Axtell et al. (2000) and West and Anderson (1996). Team leaders had to indicate quantity and quality of ideas developed within the team as well as of ideas implemented. The scale included items such as, 'Please indicate to what extent your team develops ideas concerning new products or product improvements', 'Please indicate to what extent the ideas concerning new products or product improvements were also implemented', 'When you think about your team's implemented ideas, how would you assess their novelty?'. All items were rated on a 7-point scale ranging from 1 (e.g., no new ideas implemented) to 7 (e.g., many new ideas implemented).

\section{Control Variables}

As team size has been found to impact innovation-related team processes and team 
innovation (Dailey, 1978; Curral et al., 2001) we decided to use it as a control variable and, therefore, asked team members for the size of their team. We also asked team members for team longevity because research results point at a negative relationship between team longevity and team creativity and innovation (e.g., Nyström, 1979; Katz, 1982, 1988; Lovelace, 1986; West \& Anderson, 1996). Further, we controlled for transactional leadership because it is regarded as a prerequisite for transformational leadership style. Some studies report negative intercorrelations between the different sub-scales for transactional leadership (see Geyer \& Steyrer, 1994; Lowe, Kroeck \& Sivasubramaniam, 1996; Avolio, Bass \& Jung, 1999). Therefore, we followed the approach of Lowe, Kroeck and Sivasubramaniam (1996) and measured transactional leadership by using the contingent reward scale from the MLQ which contained 4 items and showed good internal homogeneity (Cronbach's alpha $=0.82$ ). In line with our expectations, a principal component analysis showed that the transactional leadership items all loaded on one factor that explained 71.53 per cent of the variance. A sample item is "The leader makes clear what one can expect to receive when performance goals are achieved.'

\section{Results}

\section{Validity and Reliability Analyses}

In order to assess the dimensional structure of our measure of transformational leadership, we conducted a confirmatory factor analysis using AMOS 5.0 to test a two-level factor model. According to Bass' (1985) conception of transformational leadership, this model contained the four components of transformational leadership as four different factors at the first level and conceptualized transformational leadership as underlying single factor at the second level. As modification indices indicated that the 11th item could best be left out of the analysis we conducted the confirmatory factor analyses without this item. We found support for the expected two-level factor structure, $\chi^{2}(148, N=256) / d f=3.30, C F I=$ 0.89 , RMSEA $=0.09$. In contrast, a simple one-factor model showed no acceptable model fit, $\chi^{2}(148, N=256) / d f=5.96, \quad C F I=0.76$, RMSEA $=0.14$. Cronbach's alpha for transformational leadership was 0.96 , indicating excellent internal homogeneity.

As the scale used for measuring team innovation comprised 22 items, the sample size of the team leaders $(N=52)$ was too small to conduct any factor analysis in order to test for the scale's expected single-factor structure. However, Cronbach's alpha for team innovation was 0.93 , indicating excellent internal homogeneity.

\section{Aggregation Analyses}

In order to justify aggregation of transformational leadership ratings to the team level, we analysed both the amount of within-group variance and the amount of between-group variance. We assessed within-group variance by calculating the $r_{w g}$ index (James, Demaree \& Wolf, 1984). $R_{w g}$ for transformational leadership was 0.96, indicating excellent inter-rater agreement. Further, we performed a one-way analysis of variance (ANOVA) for the transformational leadership scale in order to assess the amount of between-group variance. The $F$-value was statistically significant $(F=2.31$, $p<0.01)$, indicating substantial differences between groups.

\section{Descriptive Statistics}

Table 1 presents means and standard deviations for all variables in the study as well as their intercorrelation matrix.

Table 1. Means, Standard Deviations, and Intercorrelations of Variables

\begin{tabular}{|c|c|c|c|c|c|c|c|}
\hline Variable & $M$ & $S D$ & 1 & 2 & 3 & 4 & 5 \\
\hline 1 Team size & 9.14 & 4.23 & - & & & & \\
\hline 2 Team longevity & 39.23 & 33.61 & 0.05 & - & & & \\
\hline 3 Transactional leadership & 5.07 & 0.67 & -0.14 & -0.12 & - & & \\
\hline 4 Tranformational leadership & 5.09 & 0.79 & -0.12 & -0.03 & $0.71^{*}$ & - & \\
\hline 5 Team innovation & 4.80 & 0.69 & -0.08 & -0.10 & 0.07 & 0.01 & - \\
\hline
\end{tabular}

Note: $N=52 .{ }^{*} \mathrm{p}<0.05$ two-tailed. 
Table 2. Hierarchical Regression Analysis

\begin{tabular}{lccc}
\hline Variable & \multicolumn{3}{c}{ R\&D team innovation } \\
\cline { 2 - 3 } & $\beta$ & $p$ & $\Delta R^{2}$ \\
\hline Step 1: Control variables & & & \\
Team size & 0.141 & 0.346 & 0.018 \\
Team longevity & -0.069 & 0.642 & \\
Transactional leadership & 0.085 & 0.789 & 0.008 \\
Step 2: Predictor & & & \\
Transformational leadership & -0.031 & 0.924 & 0.085 \\
Step 3: Squared term & & & \\
Transformational leadership & & \\
\end{tabular}

Note: $N=52$.

\section{Hypothesis Testing}

In order to test our hypothesis about a U-shaped relationship between transformational leadership on team innovation, we conducted a hierarchical regression analysis with team innovation used as dependent variable. In the first step, we entered team size, team longevity and transactional leadership as control variables into the regression model. In the second step, we entered transformational leadership as predictor. Following the recommendations of Aiken and West (1996) for testing curvilinear effects, transformational leadership as predictor variable was centred beforehand. In the third step, we entered the squared term of transformational leadership as predictor. Our results showed no significant relationships between the control variables and team innovation (see Table 2 for all statistics). In addition, the linear relationship between transformational leadership and team innovation was not significant either $\left(\beta=-0.031, p=0.924, \Delta R^{2}=0.008\right)$. However, in line with our expectations, the squared term of transformational leadership was a significant predictor of team innovation $(\beta=0.319$, $p<0.05, \Delta R^{2}=0.085$ ).

We plotted the curvilinear relationship between transformational leadership and team innovation. Figure 1 shows the U-shaped relationship between transformational leadership and team innovation, thus confirming our hypothesis.

\section{Discussion}

This study sheds light on the role that leadership plays for R\&D team innovation by reconciling two contradictory positions. Whereas innovation research suggests giving R\&D team members a high level of intellectual autonomy (e.g., Kim, Min \& Cha, 1999), leadership research points at transformational leadership as a lever to facilitate R\&D team innovation (Waldman \& Bass, 1991). We predict and confirm a U-shaped relationship between transformational leadership and R\&D team innovation. Hence, R\&D team innovation was high both under high and low levels of transformational leadership. In contrast, R\&D team innovation was low under moderate levels of transformational leadership. To the best of our knowledge, this is the first study investigating a non-linear relationship between transformational leadership and innovation in $R \& D$ teams.

As $R \& D$ teams are creative and innovative under low and high levels of transformational leadership, the question arises whether high levels of transformational leadership are necessary at all in the R\&D context. Trusting in R\&D team members' high intrinsic motivation to innovate and their expert knowledge and thereby protecting their intellectual autonomy thus seem to be as effective as providing high levels of transformational leadership.

Moderate levels of transformational leadership, however, will be linked to low levels of R\&D team innovation because it is likely to endanger team members' intellectual autonomy without realizing the full innovation-beneficial potential of transformational leadership. Thus, not any level of transformational leadership will result in high team innovation. R\&D team leaders who display moderate levels of transformational leadership should therefore receive transformational leadership training. Empirical research confirmed the efficacy of training programmes 


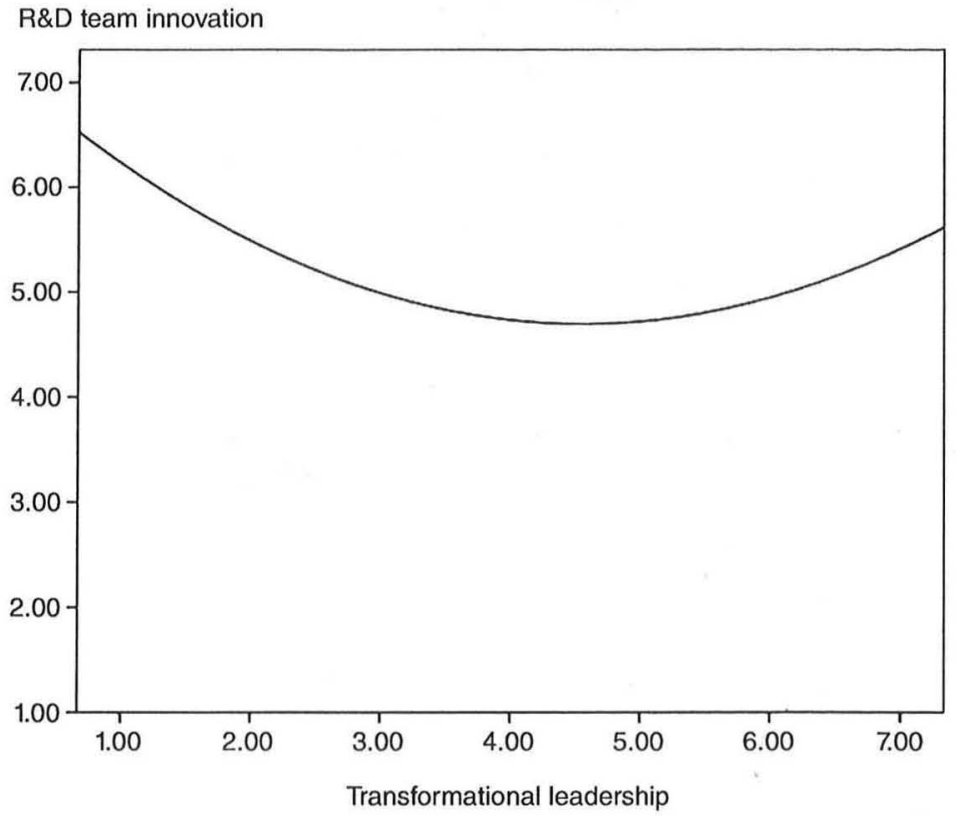

Figure 1. The U-shape Relationship between Transformational Leadership and RED Team Innovation

focused on intensifying transformational leadership (Barling, Weber \& Kelloway, 1996; Avolio, 1999).

\section{Limitations}

Our study does have some limitations. First, because of our cross-sectional design we do not know about the causal direction of the relationship between transformational leadership and R\&D team innovation. Second, we used a subjective measure of $R \& D$ team innovation. It would have been revealing to also use objective measures of R\&D team innovation (e.g., number of patents) and eventually compare subjective to objective team innovation measures. However, because of practical constraints, it was not possible to collect objective data in our study. Third, caution should be exercised in applying our results to other forms of organizational teams. In order to do so, we recommend replicating the study within other organizational contexts.

\section{References}

Aiken, L.S. and West, S.G. (1996) Multiple Regression: Testing and Interpreting Interactions. Sage Publications, Newbury Park, CA.

Amabile, T.M. (1988) A Model of Creativity and Innovation in Organizations. Research in Organizational Behavior, 10, 123-67.
Amabile, T.M. and Gryskiewicz, N.D. (1989) The Creative Environment Scales: Work Environment Inventory. Creativity Research Journal, 2, 231-53.

Anderson, N.R. and King, N. (1993) Innovation in Organization. International Review of Industrial and Organizational Psychology, 8, 1-34.

Anderson, N.R., de Dreu, C.K.W. and Nijstad, B.A. (2004) The Routinization of Innovation Research: A Constructively Critical Review of the State-ofthe-Science. Journal of Organizational Behavior, 25, 147-73.

Arthur D. Little. (2004) Innovation Excellence Studie 2004. Arthur D. Little, Wiesbaden.

Avolio, B.J. (1994) Total Quality and Leadership. In Bass, B.M. and Avolio, B.J. (eds.), Improving Organizational Effectiveness through Transformational Leadership. Sage Publications, Thousand Oaks, CA, pp. 121-45.

Avolio, B.J. (1999) Full Leadership Development. Sage Publications, Thousand Oaks, CA.

Avolio, B.J. and Bass, B.M. (1988) Transformational Leadership, Charisma, and Beyond. In Hunt, J.G., Baliga, B.R., Dachler, H.P. and Schriesheim, C.A. (eds.), Emerging Leadership Vistas. Lexington Books, Lexington, MA, pp. 29-49.

Avolio, B.J., Bass, B.M. and Jung, D.I. (1999) Re-Examining the Components of Transformational and Transactional Leadership using the Multifactor Leadership Questionnaire. Journal of Occupational and Organizational Psychology, 72, 441-62.

Axtell, C.M., Holman, D.J., Unsworth, K.L., Wall, T.D., Waterson, P.E. and Harrington, E. (2000) Shopfloor Innovation: Facilitating the Suggestion and Implementation of Ideas. Journal of Occupational and Organizational Psychology, 73, 265-85. 
Bandura, A. (1998) Self-Efficacy: The Exercise of Control. Freeman and Company, New York.

Barling, J., Weber, T. and Kelloway, E.K. (1996) Effects of Transformational Leadership Training on Attitudinal and Financial Outcomes: A Field Experiment. Journal of Applied Psychology, 81, 82732.

Bass, B.M. (1985) Leadership and Performance beyond Expectations. Free Press, New York.

Bass, B.M. (1998) Transformational Leadership: Industry, Military, and Educational Impact. Lawrence Erlbaum Associates, Mahwah, NJ.

Bass, B.M. and Avolio, B.J. (1994) Improving Organizational Effectiveness through Transformational Leadership. Sage Publications, Thousand Oaks, CA.

Bass, B.M. and Avolio, B.J. (1995) MLQ Multifactor Leadership Questionnaire. Technical Report. Mind Garden, Redwood City, CA.

Bass, B.M. and Riggio, R.E. (2006) Transformational Leadership. Lawrence Erlbaum Associates, Mahwah, NJ.

Bass, B.M., Avolio, B.J., Jung, D.I. and Berson, Y. (2003) Predicting Unit Performance by Assessing Transformational and Transactional Leadership. Journal of Applied Psychology, 88, 207-18.

Burns, J.M. (1978) Leadership. Harper \& Row, New York.

Cho, H. and Pucik, V. (2005) Relationship between Innovativeness, Quality, Growth, Profitability, and Market Value. Strategic Management Journal, 26, 555-75.

Conger, J.A. and Kanungo, R.N. (1992) Perceived Behavioural Attributes of Charismatic Leadership. Canadian Journal of Behavioural Science, 24, 86-102.

Curral, L.A., Forrester, R.H., Dawson, J.F. and West, M.A. (2001) It's What You Do and the Way that You Do It: Team Task, Team Size, and InnovationRelated Group Processes. European Journal of Work and Organizational Psychology, 10, 187204.

Dailey, R.C. (1978) The Role of Team and Task Characteristics in R\&D Team Collaborative Problem Solving and Productivity. Management Science, 24, 1579-88.

Deci, E.L., Connell, J.P. and Ryan, R.M. (1989) SelfDetermination in a Work Organization. Journal of Applied Psychology, 74, 580-90.

Dougherty, D. (2006) Organizing for innovation in the 21st century. In Clegg, S., Hardy, C., Lawrence, T. and Nord, W.R. (eds.), The Sage Handbook of Organization Studies. Sage Publications, London, pp. 598-617.

Eisenbeiß, S.A., van Knippenberg, D. and Boerner, S. (2008) Transformational Leadership and Team Innovation: Integrating Team Climate Principles. Journal of Applied Psychology, 93, 1438-46.

Elkins, T. and Keller, R.T. (2003) Leadership in Research and Development Organizations: A Literature Review and Conceptual Framework. The Leadership Quarterly, 14, 587-606.

Friedman, L., Fleishman, E.A. and Mikula Fletcher, J. (1992) Cognitive and Interpersonal Abilities Related to the Primary Activities of R\&D Managers. Journal of Engineering and Technological Management, 9, 211-42.
Geyer, A.L.J. and Steyrer, J. (1994) Transformationale Führung, klassische Führungstheorien und Erfolgsindikatoren von Bankbetrieben. Zeitschrift für Betriebswirtschaft, 64, 961-79.

Gully, S.M., Incalcaterra, K.A., Joshi, A. and Beaubien, J.M. (2002) A Meta-Analysis of TeamEfficacy, Potency, and Performance: Interdependence and Level of Analysis as Moderators of Observed Relationships. Journal of Applied Psychology, 87, 819-32.

James, L.R., Demaree, R.G. and Wolf, G. (1984) Estimating Within-group Interrater Reliability with and without Response Bias. Journal of Applied Psychology, 69, 85-98.

Janz, B.D., Colquitt, J.A. and Noe, R.N. (1997) Knowledge Worker Team Effectiveness: The Role of Autonomy, Interdependence, Team Development, and Contextual Support Variables. Personnel Psychology, 50, 877-904.

Judge, T.A., Woolf, E.F., Hurst, C. and Livingston, B. (2006) Charismatic and Transformational Leadership: A Review and Agenda for Future Research. Zeitschrift für Arbeits- und Organisationspsychologie, 50, 203-14.

Jung, D.I., Chow, C. and Wu, A. (2003) The Role of Transformational Leadership in Enhancing Organizational Innovation: Hypotheses and Some Preliminary Findings. The Leadership Quarterly, 14, $525-44$.

Kanter, R.M. (1988) When a Thousand Flowers Bloom: Structural, Collective, and Social Conditions for Innovation in Organization. Research in Organizational Behavior, 10, 169-211.

Kark, R., Shamir, B. and Chen, G. (2003) The Two Faces of Transformational Leadership: Empowerment and Dependency. Journal of Applied Psychology, 88, 246-55.

Katz, R. (1982) The Effects of Group Longevity on Project Communication and Performance. Administrative Science Quarterly, 27, 81-104.

Katz, R. (1988) Managing Careers: The Influence of Job and Group Longevities. In Tushman, M.L. and Moore, W.L. (eds.), Readings in the Management of Innovation. Ballinger, Cambridge, pp. 196212.

Keller, R.T. (1992) Transformational Leadership and the Performance of Research and Development Project Groups. Journal of Management, 18, 489501.

Keller, R.T. (2006) Transformational Leadership, Initiating Structure, and Substitutes for Leadership: A Longitudinal Study of Research and Development Project Team Performance. Journal of Applied Psychology, 91, 202-10.

Kim, Y., Min, B. and Cha, J. (1999) The Roles of R\&D Team Leaders in Korea: A Contingent Approach. RED Management, 18, 153-65.

Kurtzberg, T.R. and Amabile, T.M. (2001) From Guilford to Creative Synergy: Opening the Black Box of Team-Level Creativity. Creativity Research Journal, 13, 285-94.

Lovelace, R.F. (1986) Stimulating Creativity through Managerial Intervention. RED Management, 16, 161-74.

Lowe, K.B., Kroeck, K.G. and Sivasubramaniam, N. (1996) Effectiveness Correlates of Transformational and Transactional Leadership: A 
Meta-Analytic Review of the MLQ Literature. The Leadership Quarterly, 7, 385-425.

Mumford, M.D., Scott, G.M., Gaddis, B. and Strange, J.M. (2002) Leading Creative People: Orchestrating Expertise and Relationships. The Leadership Quarterly, 13, 705-50.

Northouse, P.G. (2007) Leadership: Theory and Practice. Sage Publications, Thousand Oaks, CA.

Nyström, H. (1979) Creativity and Innovation. John Wiley \& Sons, Chichester.

Oldham, G.R. and Cummings, A. (1996) Employee Creativity: Personal and Contextual Factors at Work. Academy of Management Journal, 39, 607-34.

Pirola-Merlo, A. and Mann, L. (2004) The Relationship between Individual Creativity and Team Creativity: Aggregating across People and Time. Journal of Organizational Behavior, 25, 235-57.

Podsakoff, P.M., MacKenzie, S.B., Moorman, R.H. and Fetter, R. (1990) Transformational Leader Behaviors and their Effects on Followers' Trust in Leader, Satisfaction, and Organizational Citizenship Behavior. The Leadership Quarterly, 1, 107-42.

Rank, J., Pace, V.L. and Frese, M. (2004) Three Avenues for Future Research on Creativity, Innovation, and Initiative. Applied Psychology: An International Review, 53, 518-28.

Realin, J.A. (1985) The Basis for the Professional's Resistance to Managerial Control. Human Resource Management, 24, 147-75.

Schaubroeck, J., Cha, S.E. and Lam, S.S.K. (2007) Embracing Transformational Leadership: Team Values and the Impact of Leader Behavior on Team Performance. Journal of Applied Psychology, $92,1020-30$.

Shamir, B., House, R.J. and Arthur, M.B. (1993) The Motivational Effects of Charismatic Leadership: A Self-Concept Based Theory. Organization Science, 4, 577-94.

de Vries, R.E., Roe, R.A. and Taillieu, T.C.B. (1999) On Charisma and Need for Leadership. European Journal of Work and Organizational Psychology, 8, 109-33.

Waldman, D.A. and Atwater, L.E. (1994) The Nature of Effective Leadership and Championing Processes at Different Levels in a R\&D Hierarchy. Journal of High Technology Management Research, 5, 233-45.

Waldman, D.A. and Bass, B.M. (1991) Transformational Leadership at Different Phases of the Innovation Process. Journal of High Technology Management Research, 2, 169-80.

West, M.A. (1990) The Social Psychology of Innovation in Groups. In West, M.A. and Farr, J.L. (eds.), Innovation and Creativity at Work: Psychological and Organizational Strategies. John Wiley \& Sons, Chichester, pp. 309-33.

West, M.A. (2002a) Ideas are Ten a Penny: It's Team Implementation not Idea Generation that Counts.
Applied Psychology: An International Review, 51, 411-24.

West, M.A. (2002b) Sparkling Fountains or Stagnant Ponds: An Integrative Model of Creativity and Innovation Implementation in Work Groups. Applied Psychology: An International Review, 51, 355-87.

West, M.A. and Anderson, N.R. (1996) Innovation in Top Management Teams. Journal of Applied Psychology, 81, 680-93.

West, M.A. and Farr, J.L. (1990) Innovation at Work. In West, M.A. and Farr, J.L. (eds.), Innovation and Creativity at Work: Psychological and Organizational Strategies. John Wiley \& Sons, Chichester, pp. 3-13.

Yukl, G. (1998) Leadership in Organizations. PrenticeHall, Upper Saddle River, NJ.

Dr. Silke A. Eisenbeiß (silke_eisenbeiss@ hotmail.com) is Research Fellow in the Department of Organizational and Economic Psychology, LMU Munich, Germany. Her work has been published in leading journals, including Journal of Applied Psychology and Journal of Leadership and Organizational Studies. She has also contributed papers at the Academy of Management Annual Meeting 2008 in Anaheim, Academy of Management Annual Meeting 2006 in Atlanta and EURAM 2008. Her research interests include ethical leadership, 'new leadership', innovation management, group dynamics and corporate governance.

Prof. Dr. Sabine Boerner (sabine.boerner@uni-konstanz.de) is at the Department of Politics and Management, University of Konstanz, Germany. Her work has been published in leading journals, including Creativity and Innovation Management, Journal of Applied Psychology, Journal of Entrepreneurship and Innovation Management, Journal of Leadership and Organizational Studies and Human Resource Development International. Conference proceedings in which she has been published include Academy of Management Annual Meeting 2008 in Anaheim, Academy of Management Annual Meeting 2006 in Atlanta, Academy of Management Annual Meeting 2002 in Denver, EURAM 2008, EGOS 2006 and EGOS 2008. Her research interests include team leadership, cooperation and communication in organizational groups and innovation research. 